\title{
The Estimation of 4-Hydroxy-3-Methoxymandelic Acid in Urine
}

\author{
BY M. SANDLER AND C. R. J. RUTHVEN \\ Bernhard Baron Memorial Research Laboratories, Queen Charlotte's Maternity Hospital, London, W. 6
}

\section{(Received 20 January 1961)}

Armstrong \& McMillan (1957) identified 4hydroxy-3-methoxymandelic acid (vanilmandelic acid) in normal human urine and demonstrated that increased quantities were excreted after noradrenaline infusion and by patients with the catecholemine-secreting tumour, phaeochromocytoma. Subsequent work has established that 3methoxylation followed by oxidative deamination to 4-hydroxy-3-methoxymandelic acid is a major metabolic pathway of both noradrenaline and adrenaline (see Axelrod, 1959). Some 4-hydroxy-3methoxymandelic acid is also formed by an alternative pathway in which oxidative deamination precedes 3-methoxylation (Kopin, 1960).

About $45 \%$ of the total noradrenaline and adrenaline production in man is excreted as 4hydroxy-3-methoxymandelic acid (Kopin, 1960) compared with a free-amine excretion of only 1-4\% (Euler \& Luft, 1951; Goldenberg, Serlin, Edwards \& Rapport, 1954). Estimation of small concentrations of free catecholamines in urine demands specialized skills and equipment for the biological or fluorimetric procedures involved; results are often conflicting and depend on the method of assay (Goldenberg et al. 1954). Catechol compounds generally are inherently unstable. It is thus likely that 4-hydroxy-3-methoxymandelic acid, by virtue of its stability and relatively large output, will provide a better guide to noradrenaline and adrenaline turnover, if a simple technique for its assay were available. A number of quantitative techniques have been described (Armstrong, Shaw \& Wall, 1956; Robinson, Ratcliffe \& Smith, 1959; Smith, Schweitzer \& Wortis, 1959; Weise, McDonald \& LaBrosse, 1960; Studnitz \& Hanson 1959) but none of these methods is well suited to the clinical laboratory.

We have given preliminary reports of a colorimetric method for 4-hydroxy-3-methoxymandelic acid assay (Sandler \& Ruthven, 1959a,b). The modification described here is both simpler and more specific. It involves the absorption of urinary 4-hydroxy-3-methoxymandelic acid on an anion-exchange resin, and its elution, extraction and subsequent conversion into vanillin, which is measured spectrophotometrically. Apart from its value in the diagnosis of phaeochromocytoma, it is suitable for the study of small changes in 4- hydroxy-3-methoxymandelic acid output at normal excretion levels.

\section{EXPERIMENTAL}

Materials. Acetate buffers were prepared from ammonium acetate and acetic acid. Vanillin standard was prepared daily by diluting $0.2 \mathrm{ml}$. of an aq. stock solution of vanillin (A.R.) (313 mg./l.) to $25 \mathrm{ml}$. with $0.23 \mathrm{~N}-\mathrm{HCl}$ (A.R.). The stock solution was stored at $4^{\circ}$ and was prepared once a month. Aq. solution of sodium borohydride $(10 \%, w / v)$ was freshly prepared just before use. Ethyl acetate (for spectroscopic use, British Drug Houses Ltd.) and alumina (aluminium oxide M.F.C. purified neutral, Hopkin and Williams Ltd.) were used.

Dowex analytical-grade anion-exchange resin AGl-X2 (200-400 mesh; Cl form) (Bio-Rad Laboratories, Richmond, Calif., U.S.A.) was converted into its acetate form. The resin $(100 \mathrm{~g}$.) was slurried with $4 \mathrm{M}$-ammonium acetate, pH 5.9 (50 ml.) and the fines were aspirated after standing for $10 \mathrm{~min}$. The creamy mixture was poured into a column $(2.5 \mathrm{~cm} . \times 50 \mathrm{~cm}$.$) , the excess of fluid drained off, and the$ packed resin eluted with $4 \mathrm{M}$-ammonium acetate, $\mathrm{pH} 5.9$ (about $400 \mathrm{ml}$.) until the eluate was almost chloride-free. The excess of buffer was then removed by washing the column with water (about $500 \mathrm{ml}$.) and, after draining, the resin was extruded and stored damp at $4^{\circ}$.

Procedure. From $1.0 \mathrm{ml}$. (or $0.5 \mathrm{ml}$., see below) of urine diluted with $1 \mathrm{ml}$. of water an autoclaved sample was prepared as described by Sandler \& Ruthven (1959a) except that Dowex AGl-X 2 (acetate form) was used, the ethyl acetate extract was evaporated in a stream of $\mathrm{N}_{2}$ instead of in vacuo, and the evaporated extract was dissolved in $0.23 \mathrm{~N}-\mathrm{HCl}$ instead of $5 \% \mathrm{H}_{2} \mathrm{SO}_{4}$. A tube containing $2.5 \mathrm{ml}$. of vanillin standard and $0.2 \mathrm{~g}$. of alumina was autoclaved at the same time. A $2.0 \mathrm{ml}$. portion of the autoclaved solution was adjusted with $0.4 \mathrm{ml}$. of $2 \mathrm{M}$-diethanolamine to approx. $\mathrm{pH}$ 9.1. The precipitate of $\mathrm{Al}(\mathrm{OH})_{3}$ which formed removed any chromogens present and was separated by centrifuging. The clear colourless supernatant liquid was transferred to a $10 \mathrm{~mm}$. cuvette (capacity $3.5 \mathrm{ml}$.). The partly filled cell was placed in its carrier with its base raised $5 \mathrm{~mm}$. to ensure an unobstructed light-path, and the extinction read against water at 365 and $380 \mathrm{~m} \mu$. Sodium borohydride solution (approx. 0.1 ml.) was then added and after $30 \mathrm{~min}$. the extinction redetermined at 365 and $380 \mathrm{~m} \mu$ in the same cell. Obstruction of the light-path by bubbles of $\mathrm{H}_{2}$ from the borohydride was avoided by using cells freshly cleaned in chromic acid and by dislodging any bubbles that did form by sharply tapping the cuvette with the finger just before reading. The autoclaved vanillin standard was treated in a similar way. If the extinctions at wavelength $\lambda$ of autoclaved urine extracts before and after 
treatment with sodium borohydride are indicated by $T_{\lambda}$ and $\mathrm{TB}_{\lambda}$ and the corresponding extinctions of autoclaved vanillin standards by $\mathrm{S}_{\lambda}$ and $\mathrm{SB}_{\lambda}$, the amount of 4-hydroxy3-methoxymandelic acid in the urine specimen (1 or $0.5 \mathrm{ml}$.) is

$$
\frac{8 \cdot 15\left[\left(\mathrm{~T}_{385}-1 \cdot 05 \mathrm{~TB}_{365}\right)-\left(\mathrm{T}_{380}-1 \cdot 05 \mathrm{~TB}_{380}\right)\right]}{\left(\mathrm{S}_{365}-1 \cdot 05 \mathrm{SB}_{365}\right)-\left(\mathrm{S}_{380}-1 \cdot 05 \mathrm{SB}_{380}\right)} \mu \mathrm{g} .
$$

Collection of urine samples. Specimens (24 hr.) were acidified with $25 \mathrm{ml}$. of acetic acid (A.R.). Although 4hydroxy-3-methoxymandelic acid is very stable in urine, decomposition of bicarbonate during elution of an alkaline urine tends to cause disruption of the column.

\section{Comments on the method}

The eluate from two columns, one containing $100 \mu \mathrm{g}$. of 4-hydroxy-3-methoxymandelic acid in $1 \mathrm{ml}$. of water and the other $100 \mu \mathrm{g}$. in $1 \mathrm{ml}$. of urine, was collected in $1 \mathrm{ml}$. fractions. The peak level of 4-hydroxy-3-methoxymandelic acid was found in the same fraction $(9 \mathrm{ml}$.) in each column.

Extraction of 4-hydroxy-3-methoxymandelic acid from acetate buffer. Unly about 5\% of 4-hydroxy-3-methoxymandelic acid was extracted from acetate buffer with equal volumes of ethyl acetate, with or without saturation with $\mathrm{NaCl}$; however, acidification $(\mathrm{pH}<1$ ) and saturation with $\mathrm{NaCl}$ caused about $75 \%$ of the 4-hydroxy-3-methoxymandelic acid to pass into the organic phase. Two extractions with ethyl acetate removed over 90\%. Ether extraction was not as satisfactory (recovery approx. $65 \%$ after two extractions). Less than $3 \%$ loss of 4-hydroxy-3methoxymandelic acid $(10 \mu \mathrm{g}$.$) , added to ethyl acetate$ (15 ml.) previously equilibrated with acetate buffer, was detected when the solvent was removed under vacuum between $40^{\circ}$ and $100^{\circ}$. When ethyl acetate was removed by a stream of $\mathrm{N}_{2}$, recoveries of 4-hydroxy-3-methoxymandelic acid from urine were of the same order (65-75\%) as those obtained when the solvent was evaporated under vacuum.

Paper-chromatographic identification of vanillin. Autoclaved extracts of normal urine or of urine from patients with phaeochromocytoma, prepared without alumina, were evaporated to dryness at $37^{\circ}$ in an incubator. The residues were chromatographed on Whatman no. 1 filter paper by the ascending method in propan-2-ol-aq. $\mathrm{NH}_{3}$ soln. (sp.gr. 0.88)-water (20:1:2, by vol.). Two-dimensional chromatograms were also prepared with butan-1-olpyridine-water (10:3:3, by vol.) as second solvent. Papers were dried in a stream of warm air and dipped in a mixture of $0.003 \%(w / v)$ indole in ethanol-orthophosphoric acid (3:5, $v / v)$ (Sandler \& Ruthvén, 1959a). Vanillin, which was invariably present in urine extracts from normal subjects and present in increased concentration in phaeochromocytoma urine extracts, appeared as a pink spot $\left(R_{F} 0.5\right.$ in the propan-2-ol system; 0.8 in the butan-1-ol system). $p$-Hydroxybenzaldehyde, usually present in trace amounts which were not increased in phaeochromocytoma, showed as an orange spot $\left(R_{F}, 0.6\right.$ in the propan-2ol system; 0.85 in the butanol system). These were the only substances detected except for a purple spot, shown to be an artifact, near the origin in both solvent systems and an occasional faint-brown spot that developed late $\left(R_{F} \mathbf{0 . 3}\right.$ in the propan-2-ol system; 0.2 in the butanol system).
Spectrophotometric estimation of vanillin. The absorption max. of vanillin shifts to a higher wavelength with an increase in $\mathrm{pH}$ (Englis \& Wallerman, 1957). Vanillin in diethanolamine buffer, $\mathrm{pH} 9 \cdot 1$, has an absorption max. in water at $347 \mathrm{~m} \mu$ (Fig. 1). $p$-Hydroxymandelic acid, present in normal urine (Armstrong et al. 1956), is converted during autoclaving into $p$-hydroxybenzaldehyde, which has an absorption max. at $330 \mathrm{~m} \mu$ (Fig. 1). Dihydroxymandelic acid, which occurs in urine (Goodall, 1959) would presumably be similarly converted into dihydroxybenzaldehyde in the autoclave. This compound could not be detected, however, in autoclaved extracts of urine to which the parent acid had been added.

Advantage has been taken of the rapid and approximately linear change in extinction of vanillin between 360 and $380 \mathrm{~m} \mu$ (Fig. 1) to increase the specificity of the method. Thus the three values obtained when the 4hydroxy-3-methoxymandelic acid concentration of urine was calculated at $360-380 \mathrm{~m} \mu, 365-380 \mathrm{~m} \mu$ and 370 $380 \mathrm{~m} \mu$ agreed closely with each other (15 experiments). Further precision has been obtained by measuring extinction before and after the addition of sodium borohydride to the alkaline solution. Vanillin is reduced and its reduction products show negligible absorption at 365 or $380 \mathrm{~m} \mu$ (Pisano, 1960). Under the conditions used, vanillin obeys Beer's Law up to an extinction difference (365$380 \mathrm{~m} \mu$ ) of 0.8 .

When the observed curve of the autoclaved extract from a typical normal urine (curve $A$, Fig. 2a) was corrected for non-reducible material (curve $E$ ) the resultant curve $(B)$ did not coincide in shape or height with a theoretical curve $(D)$ for vanillin at a concentration calculated to be present in the extract. Curve $D$ was constructed from the known curve of pure vanillin at a concentration equal to that obtained by applying the formula given above to the relevant extinction measurements of the extract. This

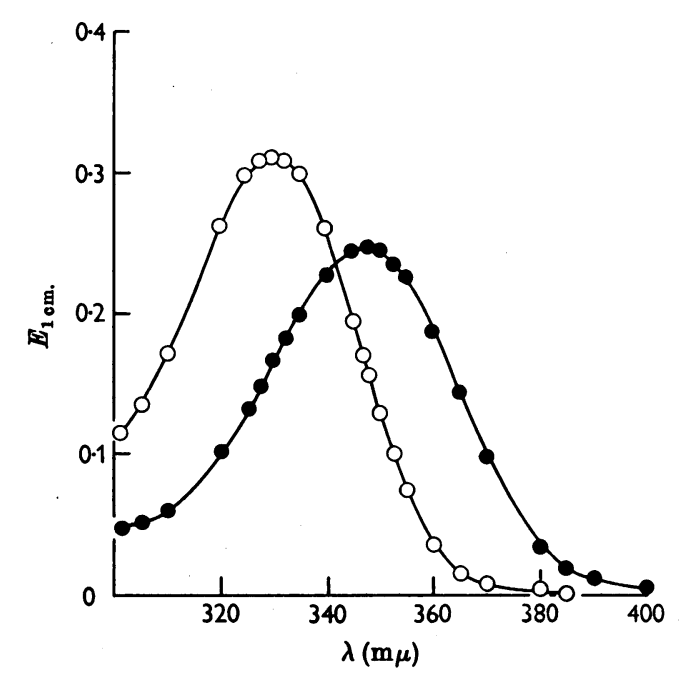

Fig. 1. Absorption spectra of vanillin (O), $\left(\lambda_{\max } 347 \mathrm{~m} \mu\right)$, and $p$-hydroxybenzaldehyde (O), $\left(\lambda_{\max } 330 \mathrm{~m} \mu\right)$. The compounds $(1.4 \mu \mathrm{g} . / \mathrm{ml}$.) were dissolved in $2 \mathrm{ml}$. of $0.23 \mathrm{~N}$ $\mathrm{HCl}$ and the solutions adjusted to about $\mathrm{pH} 9.1$ with $0.4 \mathrm{ml}$. of $2 \mathrm{M}$-diethanolamine. 

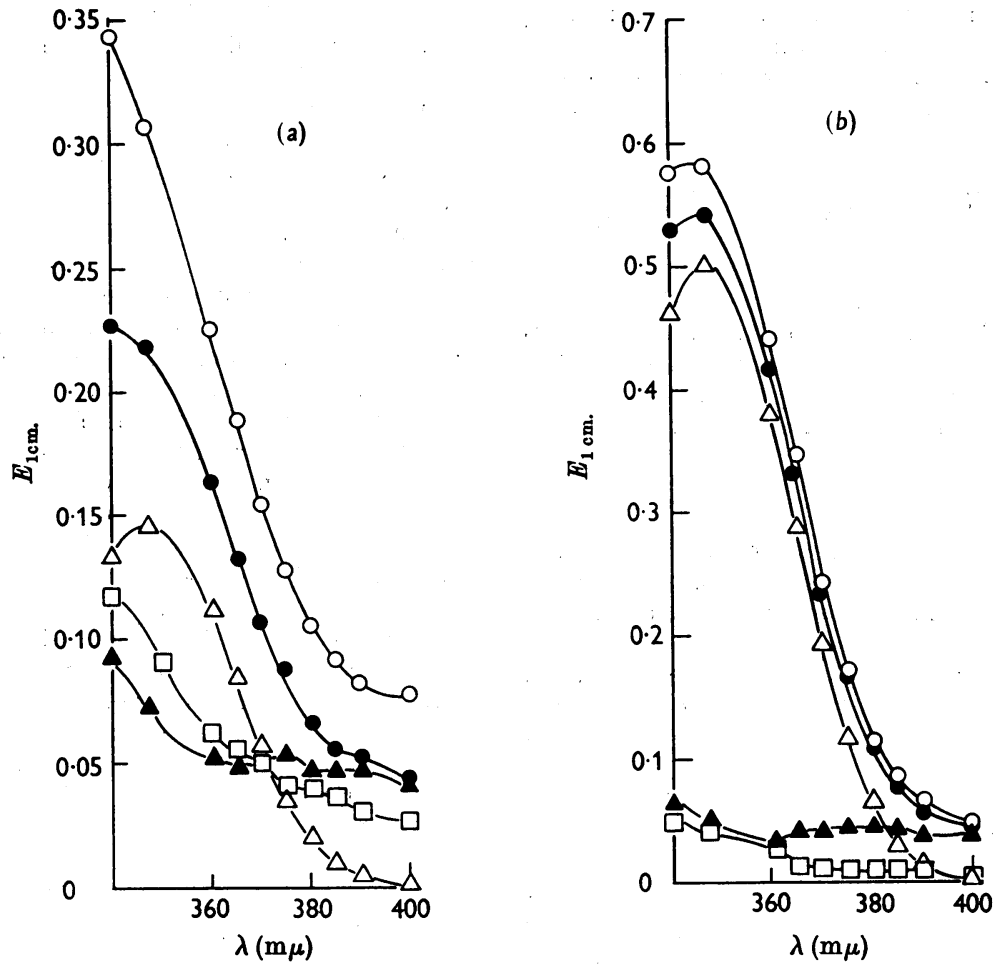

Fig. 2. Absorption spectra derived from autoclaved extracts (pH 9.1) from (a) normal urine and (b) phaeochromocytoma. Curve $A(O)$, before reduction; curve $B(\Theta)$, borohydride reducible substances; curve $C$ ( $\Delta$ ), non-vanillin reducible substances; curve $D(\Delta)$, vanillin constructed by calculation from formula; curve $E$ (口), non-reducible substances.

Table 1. 4-Hydroxy-3-methoxymandelic acid in $24 \mathrm{hr}$. urine specimens

\begin{tabular}{|c|c|}
\hline Urine & $\begin{array}{l}\text { 4-Hydroxy-3- } \\
\text { methoxymandelic acid } \\
\text { (mg./24 hr.) }\end{array}$ \\
\hline 1 & $2 \cdot 5,2 \cdot 7$ \\
\hline 2 & $3 \cdot 0, \mathbf{3} \cdot \mathbf{1}, \mathbf{3} \cdot 2$ \\
\hline 3 & $3 \cdot 6,4 \cdot 0,3 \cdot 9$ \\
\hline 4 & $4 \cdot 9,5 \cdot 0,4 \cdot 7$ \\
\hline 5 & $4 \cdot 2,4 \cdot 6,4 \cdot 5,4 \cdot 2,4 \cdot 5$ \\
\hline 6 & $2 \cdot 0,2 \cdot 4,2 \cdot 1$ \\
\hline 7 & $3 \cdot 7,3 \cdot 8,3 \cdot 9$ \\
\hline $\begin{array}{l}8 \\
9\end{array}$ & $\begin{array}{l}4 \cdot 0,4 \cdot 0 \\
4 \cdot 2,4 \cdot 0,4 \cdot 0,4 \cdot 7\end{array}$ \\
\hline 10 & $2 \cdot 8,2 \cdot 5$ \\
\hline
\end{tabular}

difference between the curves (curve $C$ ) was produced by reducible material other than vanillin, which has not been identified. When the vanillin content of the extract was relatively high, as in urine from patients with phaoochromocytoma (Fig. $2 b$ ), curves $B$ and $D$ are nearly coincident; for, whereas the concentration of reducible non-vanillin substances was similar to that in extracts of normal urine, its percentage contribution to total extinction was much lower. As the absorption curve of non-vanillin reducible material was practically flat between 365 and $380 \mathrm{~m} \mu$, even in normal urine (six subjects), its effect on the assessment of true vanillin, and therefore of 4-hydroxy-3-methoxy- mandelic acid content, was minimized by the differential method of calculation.

Recovery of 4-hydroxy-3-methoxymandelic acid from water and urine. Replication of estimations appeared to be adequate (Table 1 ) and there was no great variation in the recovery of 4-hydroxy-3-methoxymandelic acid added to urine or water between concentrations of 1.25 and $100 \mu \mathrm{g} . /$ ml. (Table 2). The recovery of 4-hydroxy-3-methoxymandelic acid from urine $(73 \pm 6.6 \%$ s.D., 28 determinations) was similar to that from water $(67 \pm 5 \cdot 3 \%$ s.D., 23 determinations). Recoveries of only $40-56 \%$ of added 4-hydroxy-3-methoxymandelic acid were obtained from fresh concentrated urine specimens (8), whereas 65-75\% was usually recovered from more dilute urine (5). By using $0.5 \mathrm{ml}$. of urine instead of $1.0 \mathrm{ml}$., and diluting with $1.0 \mathrm{ml}$. of water before running into the resin, the recovery of $2.5 \mu \mathrm{g} . / \mathrm{ml}$. of added 4-hydroxy-3-methoxymandelic acid was raised from 55 to $85 \%$ and from 56 to $83 \%$ respectively in two different concentrated specimens. It was only necessary to use $0.5 \mathrm{ml}$. of urine instead of $1 \mathrm{ml}$. when the volume of the $24 \mathrm{hr}$. specimen was less than $1200 \mathrm{ml}$.

\section{RESULTS}

The excretion of 4-hydroxy-3-methoxymandelic acid by 15 normal young adults in $24 \mathrm{hr}$. was 2.1-5.2 mg. (mean 3.9 \pm 0.7 s.D.). This range was 
lower than those reported by Sandler \& Ruthven $(1959 a, b)$. The present range is in better agreement with the values found by other workers (see Studnitz, 1960). This is largely accounted for by the measurement of vanillin by differential spectrophotometry which was subject to less interference from other materials than the previous colorimetric estimation and gave reproducible values (Table 1). A marked rise in 4-hydroxy-3methoxymandelic acid output occurred in every patient with phaeochromocytoma examined. These concentrations returned to normal within 7 days after the tumour tissue had been removed (Table 3 ).

There is no evidence to suggest that the constituents of a general diet interfere with the assay. Ingestion of coffee, which may give falsely high

Table 2. Recovery of 4-hydroxy-3-methoxymandelic acid added to urine or water

4-Hydroxy-3-methoxymandelic acid was added to $1.0 \mathrm{ml}$. of water, $1.0 \mathrm{ml}$. of urine (1) and $0.5 \mathrm{ml}$. of urine (2), the urines containing respectively 1.6 and $5.2 \mu \mathrm{g}$. of endogenous 4-hydroxy-3-methoxymandelic acid/ml.

\begin{tabular}{|c|c|c|c|}
\hline \multirow{2}{*}{$\begin{array}{l}\text { 4-Hydroxy- } \\
\text { 3-methoxy- } \\
\text { mandelic } \\
\text { acid added } \\
(\mu \mathrm{g} . / \mathrm{ml} .)\end{array}$} & \multicolumn{3}{|c|}{ Percentage recovery from } \\
\hline & Water & Urine 1 & Urine 2 \\
\hline $\begin{array}{l}1 \cdot 25 \\
2 \cdot 5 \\
5 \\
10 \\
20 \\
50 \\
100\end{array}$ & $\begin{array}{l}77,74,64,68 \\
66,72,72,72 \\
70,66,68,70 \\
62,65 \\
65,68,54,62 \\
62,65 \\
70,58,63\end{array}$ & $\begin{array}{l}\mathbf{7 6}, 84 \\
\mathbf{7 4 ,} 78 \\
80,78 \\
77,72 \\
77,78 \\
66,71 \\
65,68\end{array}$ & $\begin{array}{l}66,91 \\
76,68 \\
74,69 \\
69,81 \\
73,76 \\
63,63 \\
70,70\end{array}$ \\
\hline
\end{tabular}

Table 3. Excretion of 4-hydroxy-3-methoxymandelic acid in patients with proven phaeochromocytoma before and after tumour removal

\begin{tabular}{|c|c|c|c|}
\hline \multirow[b]{2}{*}{ Case } & \multicolumn{2}{|c|}{$\begin{array}{l}\text { 4-Hydroxy-3-methoxymandelic } \\
\text { acid excreted (mg./24 hr.) }\end{array}$} & \multirow{2}{*}{$\begin{array}{l}\text { Period between } \\
\text { tumour remova } \\
\text { and collection } \\
\text { of urine } \\
\text { (days) }\end{array}$} \\
\hline & Pre-operative & $\begin{array}{c}\text { Post- } \\
\text { operative }\end{array}$ & \\
\hline 1 & $14 \cdot 1$ & $5 \cdot 6$ & 14 \\
\hline 2 & $15 \cdot 5$ & $4 \cdot 2$ & 9 \\
\hline 3 & $10 \cdot 1$ & $6 \cdot 9$ & 4 \\
\hline 4 & $11 \cdot 6,10 \cdot 8,12 \cdot 8$ & $4 \cdot 6$ & 29 \\
\hline $5^{*}$ & $14 \cdot 6,12 \cdot 7,11 \cdot 5$ & $1 \cdot 1,1 \cdot 3$ & 3,7 \\
\hline 6 & $14 \cdot 3$ & - & - \\
\hline 7 & $15 \cdot 5$ & - & - \\
\hline 8 & $18 \cdot 6,28 \cdot 3$ & - & - \\
\hline 9 & $19 \cdot 6$ & - & - \\
\hline 10 & $47 \cdot 0$ & - & 一 \\
\hline 11 & $14 \cdot 9$ & - & - \\
\hline 12 & $27 \cdot 5$ & - & - \\
\hline 13 & $30 \cdot 0$ & - & - \\
\hline 14 & $13 \cdot 0,20 \cdot 4$ & - & - \\
\hline 15 & $23 \cdot 5$ & - & - \\
\hline 16 & $17 \cdot 0$ & - & - \\
\hline
\end{tabular}

Table 4. Recovery of 4-hydroxy-3-methoxymandelic acid $(2 \cdot 5 \mu \mathrm{g} . / \mathrm{ml}$.) from urines

The number of specimens is given in parentheses.

$$
\text { Description of urine Percentage recovery }
$$

With added glucose

$$
\begin{array}{ll}
2 \%(w / v)(2) & 83 ; 82,82 \\
5 \%(w / v)(1) & 78,86
\end{array}
$$

From patients with proteinuria

$$
\begin{aligned}
& 1 \cdot 1 \mathrm{~g} \text {. of protein/l. (1) } \quad 56,60 \\
& 1.5 \mathrm{~g} \text {. of protein } / 1 \text {. (1) } 67 \\
& 1.9 \mathrm{~g} \text {. of protein/l. (1) } \quad 62,66 \\
& 2.5 \mathrm{~g} \text {. of protein/l. (1) 72, } 72 \\
& \text { Phenylketonuria (2) } \\
& \text { Maple syrup urine disease (1) } \\
& \text { After salicylate ingestion (3) } \\
& 83,70,70 ; 67,80 \\
& 76,70,78 \\
& 72,72 ; 82,78 ; 56,70
\end{aligned}
$$

readings in a qualitative test for 4-hydroxy-3methoxymandelic acid (Gitlow, Ornstein, Mendlowitz, Khassis \& Kruk, 1960), did not bring about any apparent increase of 4-hydroxy-3-methoxymandelic acid excretion in two successive 4-hourly urine samples ( $30 \mathrm{~g}$. of 'Nescafe', one subject). Although bananas contain high concentrations of noradrenaline (Waalkes, Sjoerdsma, Creveling, Weissbach \& Udenfriend, 1958) their ingestion (12 g./kg. body wt., five subjects) did not give rise to any increased 4-hydroxy-3-methoxymandelic acid excretion in eight successive hourly urine samples, when compared with a base-line value. This confirms the findings of Studnitz (1960). After $15 \mathrm{mg}$. of oral noradrenaline (one subject) no rise in 4-hydroxy-3-methoxymandelic acid output was detected in eight successive hourly samples. Even when 4-hydroxy-3-methoxymandelic acid itself was given orally (one subject) only about $35 \%$ was recovered in urine collected hourly during the next $8 \mathrm{hr}$., by which time endogenous excretion levels had been reached. This is in general agreement with the findings of Armstrong \& McMillan (1959). Oral isoprenaline sulphate (40 mg., one subject) had no effect on 4-hydroxy-3methoxymandelic acid excretion, as noted by Gitlow, Mendlowitz, Khassis, Cohen \& Sha (1960).

The only drug whose ingestion so far has been found to interfere with the estimation is $p$-acetamidophenol. A subject excreted $300 \mu \mathrm{g}$. of 4hydroxy-3-methoxymandelic acid in the $60 \mathrm{~min}$. before ingestion of $2 \mathrm{~g}$. of $p$-acetamidophenol. After dosage the value obtained was $1 \mathrm{mg}$. in $100 \mathrm{~min}$. and $1.56 \mathrm{mg}$. in the next hour. The apparent increase in excretion was caused not by hydroxymethoxymandelic acid but by a substance with a different absorption curve from that of vanillin. Salicylate, which increases the extinction in the colorimetric method of Sandler \& Ruthven $(1959 a, b)$, does not affect the present method. Recovery of 4-hydroxy-

Bioch. 1961, 80 
3-methoxymandelic acid from urine after salicylate ingestion was apparently unchanged (Table 4), and its excretion appeared to remain within physiological limits (two experiments: 330 and $240 \mu \mathrm{g}$. in $1 \mathrm{hr}$. in control urines; 320 and $320 \mu \mathrm{g}$. after $100 \mathrm{~min}$.; 440 and $530 \mu \mathrm{g}$. after $130 \mathrm{~min}$.). No evidence was obtained that glucose, protein, urinary metabolites of maple syrup urine disease (Dancis \& Levitz, 1960) or phenylketonuria exert any effect on the recovery of 4-hydroxy-3-methoxymandelic acid from urine (Table 4).

\section{SUMMARY}

1. A method is described for measuring 4hydroxy-3-methoxymandelic acid, a major metabolite of adrenaline and noradrenaline in human urine. The assay of this acid is a convenient index of catecholamine metabolism.

2. In the procedure, 4-hydroxy-3-methoxymandelic acid is absorbed on a column of anionexchange resin and, after elution and extraction, is converted into vanillin by autoclaving with dilute acid. The vanillin is measured spectrophotometrically.

3. The accuracy and specificity of this procedure is sufficiently high to make the method suitable for following physiological fluctuations in the low concentration of 4-hydroxy-3-methoxymandelic acid $(3.9 \pm 0.7 \mathrm{mg} . / 24 \mathrm{hr}$. $)$ excreted by normal subjects. Mean recoveries from urine \pm S.D. were $73 \pm 6.6 \%$. Some factors affecting the recovery are discussed.

4. The value of the procedure as an aid to the clinical diagnosis of the catecholamine-secreting tumour, phaeochromocytoma, is demonstrated.

We are grateful to Dr Gerald Curzon for helpful dis- cussions in the preliminary stages of this work and to Dr W. W. Payne for reading the manuscript.

\section{REFERENCES}

Armstrong, M. D. \& McMillan, A. (1957). Fed. Proc. 16, 146. Armstrong, M. D. \& McMillan, A. (1959). Pharmacol. Rev. $11,394$.

Armstrong, M. D., Shaw, K. N. F. \& Wall, P. E. (1956). J. biol. Chem. 218, 293.

Axelrod, J. (1959). Physiol. Rev. 39, 751.

Dancis, J. \& Levitz, M. (1960). In The Metabolic Basis of Inherited Disease, p. 473 . Ed. by Stanbury, J. B., Wyngaarden, J. B. and Fredrickson, D. S. New York: MeGraw-Hill Book Co. Inc.

Englis, D. T. \& Wallerman, L. A. (1957). Analyt. Chem. $29,1151$.

Euler, U. S. von \& Luft, R. (1951). Brit. J. Pharmacol.6, 286.

Gitlow, S. E., Mendlowitz, M., Khassis, S., Cohen, G. \& Sha, J. (1960). J. clin. Invest. 39, 221.

Gitlow, S. E., Ornstein, L., Mendlowitz, M., Khassis, S. \& Kruk, E. (1960). Amer. J. Med. 28, 921.

Goldenberg, M., Serlin, I., Edwards, T. \& Rapport, M. M. (1954). Amer. J. Med. 16, 310.

Goodall, McC. (1959). Pharmacol. Rev. 11, 416.

Kopin, I. J. (1960). Science, 131, 1372.

Pisano, J. J. (1960). Clin. chim. Acta, 5, 406.

Robinson, R., Ratcliffe, J. \& Smith, P. (1959). J. clin. Path. 12, 541.

Sandler, M. \& Ruthven, C. R. J. (1959a). Lancet, ii, 114. Sandler, M. \& Ruthven, C. R. J. (1959b). Lancet, ii, 1034.

Smith, A. A., Schweitzer, J. W. \& Wortis, S. B. (1959). Fed. Proc. 18, 145.

Studnitz, W. von (1960). Scand. J. clin. Lab. Invest. 12, suppl. 48.

Studnitz, W. von \& Hanson, A. (1959). Scand. J. clin. Lab. Invest. 11, 101.

Waalkes, T. P., Sjoerdsma, A., Creveling, C. R., Weissbach, H. \& Udenfriend; S. (1958). Science, 127, 648.

Weise, V. K., McDonald, R. K. \& LaBrosse, E. H. (1960). Fed. Proc. 19, 294.

\title{
Teichuronic Acid: A Mucopolysaccharide Present in Wall Preparations from Vegetative Cells of Bacillus subtilis
}

\author{
By EWA JANCZURA,* H. R. PERKINS AND H. J. ROGERS \\ National Institute for Medical Research, Mill Hill, London, N.W. 7
}

\section{(Received 1 December 1960)}

Early work (Salton, 1953, 1956; Yoshida et al. 1957) showed that preparations of cell-wall material made from Bacillus subtilis are likely to be more complicated than those from some other Gram-positive organisms such as Micrococcus lysodeikticus, Staphylococcus aureus or Bacillus

* On leave from the State Institute of Hygiene, Warsaw. megaterium. Preparations from these last-named organisms revealed, after acid hydrolysis, the presence of only three or four amino acids as major components together with two amino sugars and in some instances one or two hexoses (Salton, 1953; Cummins \& Harris, 1956; Salton \& Milhaud, 1959). In some strains of the two coccal species up to $80-90 \%$ of the wall is made from four amino acids 